\title{
EFEK PENAMBAHAN MOBILISASI SCAPULA PADA MOBILISASI END-RANGE PADA PENDERITA FROZEN SHOULDER DI RUMAH SAKIT TADJUDDIN CHALID MAKASSAR
}

\section{ADDITION EFFECT MOBILIZATION OF SCAPULA ON END-RANGE MOBILIZATION ON FROZEN SHOULDER PATIENTS IN HOSPITAL TADJUDDIN MAKASSAR}

\author{
Sudaryanto ${ }^{1}$, Hermiati ${ }^{2}$ \\ 1,2Jurusan Fisioterapi Poltekkes Makassar \\ Corresponding author : sudaryanto@poltekkes-mks.ac.id
}

\begin{abstract}
ABSTRAK
Latar Belakang : Frozen shoulder atau capsulitis adhesive, adalah kondisi bahu yang ditandai dengan nyeri gerak yang hebat dan hilangnya gerakan aktif dan pasif shoulder, umumnya disebabkan oleh inflamasi dan kontraktur kapsul sendi shoulder sehingga menyebabkan keterbatasan gerak terutama eksorotasi shoulder. Metode : Penelitian ini adalah penelitian quasi ekspirimen dengan desain randomized control group pre test-post test, bertujuan untuk mengetahui efektifitas penambahan mobilisasi scapula pada mobilisasi end-range yang dikombinasikan dengan ultrasound therapy terhadap perubahan ROM dan disabilitas shoulder pada penderita frozen shoulder, dilaksanakan di Poli Fisioterapi RS. Dr. Tadjuddin Chalid Makassar dengan sampel sebanyak 14 orang, dibagi secara acak kedalam 2 kelompok yaitu kelompok perlakuan yang diberikan Ultrasound Therapy, Mobilisasi End-range dan Mobilisasi Scapula, dan kelompok kontrol diberikan Ultrasound Therapy dan Mobilisasi End-range. Hasil: Berdasarkan analisis uji paired sample $t$ pada kelompok perlakuan dan kontrol diperolah nilai $\mathrm{p}=0,000$ (ROM eksorotasi, endorotasi dan SPADI) dan $\mathrm{p}=0,002$ (abduksi) untuk kelompok perlakuan, nilai $p=0,000$ (ROM eksorotasi dan SPADI), $p=0,002$ (ROM abduksi), $p=0,012$ (ROM endorotasi) untuk kelompok kontrol, yang berarti ada pengaruh yang signifikan pada kelompok perlakuan dan kontrol terhadap peningkatan ROM Eksorotasi, Abduksi dan Endorotasi serta perbaikan disabilitas shoulder. Hasil uji independent sampel $t$ diperoleh nilai $p=0,782$ (ROM eksorotasi), $p=0,918$ (ROM abduksi), $p=0,049$ (ROM endorotasi), $\mathrm{p}=0,061$ (SPADI) yang berarti bahwa tidak ada perbedaan yang signifikan antara kedua kelompok sampel pada ROM eksorotasi, abduksi dan SPADI, namun ada perbedaan yang signifikan pada ROM endorotasi. Kesimpulan: Penambahan mobilisasi scapula pada Ultrasound dan Mobilisasi End-range tidak lebih efektif terhadap perubahan ROM Eksorotasi, Abduksi, dan disabilitas shoulder, namun lebih efektif terhadap perubahan ROM Endorotasi pada penderita Frozen Shulder.
\end{abstract}

Kata Kunci : Mobilisasi End-range, Mobilisasi Scapula, Range Of Motion, Disabilitas

\begin{abstract}
Background: Frozen shoulder or capsulitis adhesive, is a shoulder condition characterized by severe motion pain and loss of active movement and passive shoulder, is generally caused by the inflammation and contracture of the shoulder joint capsule so that it causes limited mobility especially the exhortations of the shoulder. Method: This research is the experiment research with the design randomized control group pretest-posttest, aims to determine the effectiveness of adding mobilization of scapula on end-range mobilization combined with ultrasound therapy to changes in the ROM and disability shoulder in frozen shoulder patients, conducted in Poly physiotherapy RS. Dr. Tadjuddin Chalid Makassar with a sample of 14 people, divided randomly into 2 groups of treatment group given the Ultrasound therapy, Mobilization EndRange and Mobilization of Scapula, and control group given Ultrasound therapy and Mobilization End-Range. Results: Based on the analysis of the paired sample $t$ test on the treatment and control group, the value of $p=0,000$ (ROM eksorotasi, endorotasi and $S P A D I$ ) and $p=0,002$ (reduction) for the treatment group, the value $\mathrm{P}=0,000$ (ROM eksorotasi and the SPADI), $\mathrm{p}=0,002$ (ROM abduksi), $\mathrm{p}=0,012$ (ROM endorotasi) for the control group, which means there is a significant influence on the group's treatment and control over the enhancement of ROM Eksorotasi, Abduksi and Endorotasi as well as improved shoulder disability. The result of the test Independent sample $t$ test result is obtained $p=$ 0,782 value (ROM eksorotasi), $p=0,918$ (ROM abduksi), $p=0,049$ (ROM endorotasi), $p=0,061$ (SPADI) which means that there is no significant difference between the two sample groups in exorotation ROM, abduction and SPADI, but there was a significant difference in endorotation ROM. Conclusion: The addition of the scapula mobilization on ultrasound and end-range mobilization is not more effectively to changes in ROM exorotation, abduction, and shoulder disability, but more effectively to changes in ROM endorotation patients of Frozen Shoulder.
\end{abstract}

Keywords : End-range Mobilization, Scapula mobilization, Range Of Motion, Disability. 


\section{PENDAHULUAN}

Frozen shoulder terdiri atas primer frozen shoulder dan sekunder frozen shoulder. Primer/idiopatik frozen shoulder yaitu frozen yang tidak diketahui penyebabnya, biasanya terjadi pada lengan yang tidak digunakan dan lebih memungkinkan terjadi pada orang-orang yang melakukan pekerjaan dengan gerakan bahu yang lama dan berulang. Sedangkan sekunder frozen shoulder adalah frozen yang diawali dengan trauma pada bahu misalnya fraktur, dislokasi, ataupun luka bakar yang berat meskipun cedera ini mungkin sudah terjadi beberapa tahun sebelumnya (Zuckerman, 2011).

Secara epidemiologi frozen shoulder terjadi pada usia 40-65 tahun, dimana sekitar $60 \%$ dari kasus frozen shoulder lebih banyak terjadi pada perempuan dibandingkan dengan laki-laki. Frozen shoulder juga terjadi pada $10-20 \%$ penderita diabetus mellitus yang merupakan salah satu faktor resiko frozen shoulder (Miharjanto, et al., 2010).

Prevalensi frozen shoulder adalah sekitar $2 \%$ dari populasi umum dan $10-29 \%$ pada penderita diabetes di Amerika (Shickling and Walsh, 2001). American Academic of Orthopedic Surgeons (Marinko et al, 2008) menjelaskan bahwa pravalensi nyeri bahu mencapai $50 \%$ dari populasi umum. Penelitian Luine et al (2004) dalam Kennedy et al (2006) mendapatkan data adanya kenaikan jumlah orang yang mengalami keluhan bahu yaitu rata-rata sebesar $6,9 \%$ hingga $26 \%$, kenaikan setiap 1 bulan rata-rata sebesar $18,6 \%$ hingga $31 \%$, kenaikan $4,7 \%$ hingga $46,7 \%$ setiap tahunnya, dan kenaikan rata-rata untuk beberapa tahun sebesar $6,7 \%$ hingga $66,7 \%$.

Menurut data penelitian multisenter yang dilakukan oleh kelompok studi nyeri Perhimpunan Dokter Spesialis Saraf Indonesia, menunjukkan bahwa sebagian besar pasien nyeri dan kaku bahu adalah perempuan yang berjumlah 618 pasien atau sebesar $58.7 \%$, sedangkan pada laki-laki berjumlah 434 pasien atau sebesar $41.3 \%$ (Moulin dkk 2012).

Berdasarkan hasil observasi di RS. Tadjuddin Chalid Kota Makassar selama 3 bulan terakhir (Oktober, November dan Desember), daftar kunjungan penderita frozen shoulder adalah sekitar 35 orang kunjungan dengan rata-rata 12 pasien per bulannya. Berdasarkan pengamatan peneliti di lahan praktek, ditemukan umumnya pasien yang menderita frozen shoulder tidak dapat mengangkat lengan, menyisir rambut, menjangkau beban yang lebih tinggi, mengangkat beban lebih dari $10 \mathrm{~kg}$ dan menggosok punggung saat mandi. Hal ini disebabkan karena adanya perlengketan kapsul sendi yang dipicu oleh peradangan pada kapsul sendi sehingga timbul nyeri ketika dilakukan gerakan (Morgan and Potthoff, 2012). Selain itu, posisi bahu yang cenderung protraksi pada kondisi frozen shoulder dapat mempengaruhi mobilitasi dan stabilitas fungsional scapula.

Beberapa penelitian menjelaskan bahwa strategi terapi yang digunakan untuk meningkatkan fungsi sendi regio bahu pada kondisi frozen shoulder, meliputi edukasi, excercise, elektroterapi, terapi ultrasound, terapi panas (MWD), latihan peregangan, mobilisasi sendi, mobilisasi jaringan lunak, latihan kekuatan, splint, manipulasi dalam pengaruh anastesia dan surgical contracture release ( Manske \& Brotzman, 2011).

Ultrasound merupakan salah satu modalitas yang sering digunakan pada kondisi frozen shoulder. Dalam aplikasinya, ultrasound menghasilkan efek thermal yaitu peningkatan temperature jaringan dan efek penurunan collagen ekstensibilitas, khususnya menurunkan kekentalan pada jaringan kollagen. Hal ini dapat mempermudah aplikasi mobilisasi sendi setelah pemberian ultrasound (Ebadi et.al, 2014).

Mobilisasi end-range merupakan salah satu metode Maitland yang menghasilkan efek stretching pada kapsul- ligamen. Dalam metode Maitland, teknik mobilisasi end-range yang digunakan adalah gerakan pasif oscillatory amplitudo besar yang diaplikasikan pada akhir ROM yang ada sehingga dapat menimbulkan efek stretching pada kapsul - ligamen. Hal ini dapat menghasilkan peningkatan ROM shoulder (Elly et al, 2015). 
Penambahan mobilisasi scapula pada kondisi frozen shoulder dapat memperbaiki mobilitas scapulothoracic yang ikut mengalami keterbatasan akibat dampak adanya postur protraksi scapula dalam waktu yang lama, dimana postur tersebut merupakan konsekuensi dari frozen shoulder. Selain itu, adanya gangguan stabilitas fungsional secara dinamik pada scapula akibat frozen shoulder dapat memperberat terjadinya nyeri shoulder saat lengan bergerak (Elly et al, 2015).

Berdasarkan uraian masalah diatas maka rumusan masalah penelitian ini adalah apakah ada perbedaan efek penambahan mobilisasi scapula pada mobilisasi end-range yang dikombinasikan dengan ultrasound therapy terhadap perubahan ROM dan disabilitas shoulder pada penderita frozen shoulder ? sehingga tujuan penelitian ini adalah untuk mengetahui efektifitas penambahan mobilisasi scapula pada mobilisasi end-range yang dikombinasikan dengan ultrasound therapy terhadap perubahan ROM dan disabilitas shoulder pada penderita frozen shoulder.

\section{PROSEDUR DAN METODE}

\section{Jenis Penelitian}

Jenis penelitian ini adalah penelitian quasi eksperimen dengan randomized pre test-post control group design. Penelitian ini terdiri dari 2 kelompok sampel yaitu kelompok perlakuan yang diberikan intervensi Ultrasound, Mobilisasi end-range dengan penambahan Mobilisasi scapula dan kelompok kontrol yang diberikan intervensi Ultrasound, Mobilisasi end-range.

\section{Populasi dan sampel}

Populasi penelitian ini adalah semua penderita frozen shoulder yang berkunjung atau berobat di Poli Fisioterapi RS. Tadjuddin Chalid Kota Makassar.

Sampel dalam penelitian ini adalah penderita frozen shoulder yang sesuai dengan kriteria inklusi dalam pengambilan sampel. Teknik pengambilan sampel yang digunakan adalah accidental sampling.

\section{Kriteria inklusi}

1. Penderita frozen shoulder dalam fase frozen dengan masa frozen di atas 2 bulan.

2. Keterbatasan pola kapsuler (eksorotasi >> abduksi > endorotasi)

3. Tercatat dalam medical record rumah sakit

4. Bersedia menjadi sampel dalam penelitian sampai selesai

\section{Kriteria eksklusi}

1. Penderita frozen shoulder post op mastectomy atau thoracotomy.

2. Penderita frozen shoulder post op fraktur caput atau collum humeri.

\section{Besar sampel}

Berdasarkan hasil perhitungan sampel diatas diperoleh jumlah sampel sebanyak 7,422 (dibulatkan menjadi 7) pada setiap kelompok sampel sehingga total menjadi 14 orang.

\section{Prosedur Pengumpulan Data}

Pengumpulan data diperoleh melalui data pre test dan post test yaitu pengukuran Range of Motion dan disabilitas shoulder, dengan prosedur tes adalah sebagai berikut

\section{Range of Motion Shoulder}

a. Abduksi shoulder

1) Posisi pasien : tidur terlentang

2) Posisi fisioterapis : berdiri disamping bed

3) Posisi goniometer : letakkan pusat fulcrum goniometer pada anterior dari tonjolan acromion, lengan proksimal dan distal goniometer berada disepanjang anterior midline dari humerus.

4) Prosedur pelaksanaan :

a) Instruksikan pasien untuk menggerakkan lengannya kearah abduksi shoulder.

b) Salah satu lengan goniometer mengikuti gerakan lengan kearah abduksi shoulder sambil mempertahankan lengan goniometer tetap alignment dengan midline anterior humerus. 
b. Eksternal rotasi shoulder

1) Posisi pasien : tidur terlentang

2) Posisi awal lengan pasien : abduksi shoulder $90^{\circ}$ dan fleksi elbow $90^{\circ}$ dengan alas handuk di bawah humerus

3) Posisi fisioterapis : berdiri disamping pasien

4) Posisi goniometer : fulcrum goniometer diletakkan pada tonjolan olecranon, kedua lengan goniometer tegak lurus mengikuti alignmen tulang ulna

5) Prosedur pelaksanaan :
a) Instruksikan pasien untuk menggerakkan lengannya kearah external rotasi shoulder
b) Salah satu lengan goniometer mengikuti gerakan lengan kearah external rotasi shoulder sambil mempertahankan lengan goniometer tetap alignment dengan midline tulang ulna

c. Internal rotasi shoulder

1) Posisi pasien : tidur terlentang

2) Posisi awal lengan pasien : abduksi shoulder $90^{\circ}$ dan fleksi elbow $90^{\circ}$ dengan alas handuk di bawah humerus

3) Posisi fisioterapis : berdiri disamping pasien

4) Posisi goniometer : fulcrum goniometer diletakkan pada tonjolan olecranon, kedua lengan goniometer tegak lurus mengikuti alignmen tulang ulna

5) Prosedur pelaksanaan :
a) Instruksikan pasien untuk menggerakkan lengannya kearah internal rotasi shoulder
b) Salah satu lengan goniometer mengikuti gerakan lengan kearah internal rotasi shoulder sambil mempertahankan lengan goniometer tetap alignment dengan midline tulang ulna.

2. Disabilitas shoulder
a. Alat yang digunakan : Lembar indeks SPADI
b. Prosedur pelaksanaan :

1) Jelaskan ke pasien bahwa tes ini adalah mengukur kemampuan fungsional bahu

2) Fisioterapi melingkari nilai nyeri dan disabilitas dalam indeks SPADI berdasarkan kondisi pasien dan kemampuan gerak fungsional shoulder pasien.

3. Evaluasi : Kriteria penilaian SPADI adalah
a. Mendekati $0 \%$ adalah normal
b. Mendekati $100 \%$ adalah disabilitas.

\section{Prosedur Pelaksanaan Intervensi}

Terdapat 2 kelompok sampel yaitu kelompok perlakuan yang diberikan intervensi Ultrasound, Mobilisasi End-range dengan penambahan Mobilisasi Scapula dan kelompok kontrol yang diberikan intervensi Ultrasound, Mobilisasi Scapula. Adapun prosedur pelaksanaan Ultrasound, Mobilisasi end-range dan Mobilisasi Scapula sebagai berikut :

1. Ultrasound Therapy

\section{a. Persiapan Alat}

1) Siapkan Ultrasound gel sebagai media penghantar dan mengecek kabel-kabel yang terpasang di alat.

2) Bersihkan head transduser dengan alkohol.

3) Nyalakan alat dengan menekan tombol ON/OFF.

b. Persiapan pasien

1) Fisioterapis menjelaskan kepada pasien mengenai prosedur dan tujuan dari pemberian ultrasound

2) Pasien dalam posisi tidur terlentang

3) Daerah yang akan diterapi (area bahu dan lengan) bebas dari pakaian

4) Fisioterapis mengoleskan gel secukupnya pada area shoulder bagian anterior.

c. Teknik aplikasi

1) Nyalakan alat

2) Dosis terapi adalah : frekuensi 1 $\mathrm{MHz}$, pulse ratio $100 \%$, intensitas $0,8-1 \mathrm{w} / \mathrm{cm}^{2}$, ERA tranducer $5 \mathrm{~cm}$, waktu 8 menit, jumlah intervensi sebanyak 12 kali. 
3) Fisioterapis meletakkan head transduser pada area shoulder bagian anterior.

4) Fisioterapis menekan tombol Start/Stop, kemudian menggerakkan transduser secara lambat disekitar area shoulder tersebut secara transversal.

2. Mobilisasi End-Range

a. Longitudinal Distraction : Inferior Glide Humerus

1) Posisi pasien : Tidur terlentang

2) Posisi awal lengan pasien : lengan pasien diposisikan abduksi shoulder pada ROM yang ada disertai dengan fleksi elbow

3) Posisi fisioterapis : berdiri disamping bed pasien

4) Peletakan tangan fisioterapis : satu tangan fisioterapis berada di area caput humeri bagian superior pasien sebagai penggerak gliding, satu tangan lainnya sebagai penggerak distraksi memegang epikondilus humeri sehingga tangan pasien bersandar pada lengan fisioterapis

5) Teknik Pelaksanaan

a) Instruksikan pasien untuk relaks

b) Tangan fisioterapis yang berperan sebagai penggerak gliding melakukan gerakan gliding kearah inferior sambil tangan lainnya melakukan distraksi

c) Dosis yang diberikan adalah 10 kali repetisi gerakan distraksi dengan 2 set, grade 4, jumlah intervensi sebanyak 10 kali.

b. Anterior glide caput humerus

1) Posisi pasien : Tidur tengkurap, gulungan handuk diletakkan di bawah procesus coracoideus, caput humeri berada diluar bed

2) Posisi awal lengan pasien : lengan pasien diposisikan abduksi shoulder pada ROM yang ada disertai dengan fleksi elbow
3) Posisi fisioterapis : berdiri disamping bed pasien

4) Peletakan tangan fisioterapis : satu tangan fisioterapis sebagai penggerak gliding berada di area caput humeri bagian posterior, satu tangan lainnya sebagai penggerak distraksi memegang distal humeri

5) Teknik Pelaksanaan

a) Instruksikan pasien untuk relaks

b) Tangan fisioterapis yang berperan sebagai penggerak gliding melakukan gerakan gliding kearah anterior sambil tangan lainnya melakukan distraksi

c) Dosis yang diberikan adalah 10 kali repetisi gerakan distraksi dengan 2 set, grade 4 , jumlah intervensi sebanyak 10 kali.

c. Anterior-posterior glide of head of the humerus

1) Posisi pasien : Tidur tengkurap

2) Posisi awal lengan pasien : lengan pasien diposisikan abduksi pada ROM yang ada

3) Posisi fisioterapis : duduk disamping bed pasien dan lengan bawah pasien bersandar pada knee fisioterapis

4) Peletakan tangan fisioterapis : kedua tangan fisioterapis sebagai penggerak gliding memegang caput humeri

5) Teknik Pelaksanaan

a) Instruksikan pasien untuk relaks

b) Kedua tangan fisioterapis yang berperan sebagai penggerak gliding melakukan gerakan gliding kearah anterior-posterior

c) Dosis yang diberikan adalah 10 kali repetisi gerakan distraksi dengan 2 set, grade 4 , jumlah intervensi sebanyak 10 kali. 
3. Mobilisasi scapula

a. Scapulothoracic movement medial rotation

1) Posisi pasien : tidur miring dengan mendekati tepi bed, bantal atau handuk di kepala, hip dan knee difleksikan.

2) Posisi fisioterapis : berdiri disamping bed

3) Peletakan tangan fisioterapis : satu tangan fisioterapis sebagai stabilisasi memegang area acromion pasien dari depan, dan tangan lainnya sebagai penggerak memegang margo medialis dan lateralis scapula pasien.

4) Teknik pelaksanaan :

a) Instruksikan pasien untuk relaks

b) Tangan fisioterapis yang berperan sebagai penggerak menggerakkan angulus inferior scapula kearah medial.

c) Dosis yang diberikan adalah 10 kali repetisi gerakan distraksi dengan 2 set, grade 4 , jumlah intervensi sebanyak 10 kali.

b. Scapulothoracic movement lateral rotation

1. Posisi pasien : tidur miring dengan mendekati tepi bed, bantal atau handuk di kepala, hip dan knee difleksikan.

2. Posisi fisioterapis : berdiri disamping bed

3. Peletakan tangan fisioterapis : satu tangan fisioterapis sebagai stabilisasi memegang area acromion pasien dari depan, dan tangan lainnya sebagai penggerak memegang margo medialis dan lateralis scapula pasien.

4. Teknik pelaksanaan :

a) Instruksikan pasien untuk relaks

b) Tangan fisioterapis yang berperan sebagai penggerak menggerakkan angulus inferior scapula kearah lateral.

c) Dosis yang diberikan adalah 10 kali repetisi gerakan distraksi dengan 2 set, grade 4 , jumlah intervensi sebanyak 10 kali.

\section{Hipotesis Penelitian}

Ada perbedaan efek penambahan Mobilisasi Scapula pada Mobilisasi Endrange yang dikombinasikan ultrasound therapy terhadap perubahan ROM dan disabilitas shoulder pada penderita frozen shoulder.

\section{Analisa Data}

1. Uji statistik deskriptif, untuk memaparkan karakteristik sampel berdasarkan usia dan jenis kelamin.

2. Uji normalitas data, menggunakan uji Shapiro Wilk untuk mengetahui data berdistribusi normal $(p>0,05)$

3. Uji analisis komparatif (uji hipotesis), hasil uji normalitas data menunjukkan data berdistribusi normal maka digunakan uji statistik parametrik yaitu uji paired $t$ sample dan uji independent $t$ sample.

\section{HASIL PENELITIAN}

Tabel 1 menunjukkan nilai rerata umur, dimana diperoleh nilai rerata $56.14 \pm 9.118$ tahun untuk kelompok perlakuan dan nilai $54.43 \pm 11.473$ tahun untuk kelompok kontrol. Hal ini menunjukkan bahwa rata-rata sampel tergolong kedalam usia tua baik pada kelompok perlakuan maupun kelompok kontrol. Dilihat dari nilai minimum dan maximum, diperoleh rentang umur sampel pada kelompok perlakuan adalah $40-70$ tahun dan pada kelompok kontrol adalah 40 -73 tahun.

Kemudian, dilihat dari jenis kelamin pada kelompok kontrol dan perlakuan, diperoleh sampel laki-laki sebanyak 2 orang $(28,6 \%)$ dan perempuan sebanyak 5 orang $(71,4 \%)$.

Berdasarkan tabel 2 diperoleh nilai rerata ROM eksorotasi, abduksi dan endorotasi serta SPADI (fungsional shoulder) pada kelompok perlakuan yaitu :

1. ROM eksorotasi : diperoleh pre test sebesar $45.86 \pm 6.094$ dan post test sebesar $74.57 \pm 4.61$ dengan rerata selisih sebesar $28.71 \pm 6.42$, yang berarti terjadi peningkatan ROM eksorotasi dengan rata-rata peningkatan sebesar 28.71 derajat setelah diberikan intervensi 
Ultrasound, Mobilisasi End-Range dan Mobilisasi Scapula.

2. ROM abduksi : diperoleh pre test sebesar $90.00 \pm 16.07$ dan post test sebesar $127.86 \pm 16.29$ dengan rerata selisih sebesar $37.86 \pm 18.45$, yang berarti terjadi peningkatan ROM abduksi dengan ratarata peningkatan sebesar 37.86 derajat setelah diberikan intervensi Ultrasound, Mobilisasi End-range dan Mobilisasi Scapula.

3. ROM endorotasi : diperoleh pre test sebesar $53.57 \pm 5.74$ dan post test sebesar $73 \pm 3.83$ dengan rerata selisih sebesar $19.43 \pm 6.13$, yang berarti terjadi peningkatan ROM endorotasi dengan rata-rata peningkatan sebesar 19.43 derajat setelah diberikan intervensi Ultrasound, Mobilisasi End-range dan Mobilisasi Scapula.

4. SPADI (fungsional shoulder) : diperoleh pre test sebesar $58.90 \pm 4.53$ dan post test sebesar $24.18 \pm 1.82$ dengan rerata selisih sebesar $34.72 \pm 3.31$, yang berarti terjadi penurunan disabilitas shoulder dengan rata-rata penurunan sebesar 34.72 setelah diiberikan intervensi Ultrasound, Mobilisasi End-range dan Mobilisasi Scapula.

Pada kelompok kontrol diperoleh nilai rerata ROM eksorotasi, abduksi, dan endorotasi serta SPADI (fungsional shoulder) yaitu :

1. ROM eksorotasi : diperoleh pretest sebesar $57.43 \pm 8.42$ dan post test sebesar $75.57 \pm 8.14$ dengan rerata selisih sebesar $18.14 \pm 6.54$, yang berarti terjadi peningkatan ROM eksorotasi dengan rata-rata peningkatan sebesar 18.14 derajat setelah diberikan intervensi Ultrasound dan Mobilisasi End-range.

2. ROM abduksi : diperoleh pre test sebesar $98.57 \pm 12.49$ dan post test sebesar $127.14 \pm 7.56$ dengan rerata selisih sebesar $28.57 \pm 13.76$, yang berarti terjadi peningkatan ROM abduksi dengan ratarata peningkatan sebesar 28.57 derajat setelah diberikan intervensi Ultrasound dan Mobilisasi End-range.
3. ROM endorotasi : diperoleh pre test sebesar $49.29 \pm 12.05$ dan post test sebesar $67.14 \pm 5.93$ dengan rerata selisih sebesar $17.86 \pm 13.36$, yang berarti terjadi peningkatan ROM endorotasi dengan rata-rata peningkatan sebesar 17.86 derajat setelah diberikan intervensi Ultrasound dan Mobilisasi End-range.

4. SPADI (fungsional shoulder) : diperoleh pre test sebesar $59.23 \pm 1.66$ dan post test sebesar $26.26 \pm 1.96$ dengan rerata selisih sebesar $32.97 \pm 3.03$, yang berarti terjadi penurunan disabilitas shoulder dengan rata-rata penurunan sebesar 32.97 setelah diberikan intervensi Ultrasound dan Mobilisasi End-range.

Berdasarkan tabel 3 diperoleh hasil uji paired sample $t$ yaitu nilai $\mathrm{p}<0,05$ untuk ROM eksorotasi, abduksi dan endorotasi serta SPADI (fungsional shoulder), yang berarti bahwa intervensi Ultrasound, Mobilisasi End-range dan Mobilisasi scapula dapat memberikan peningkatan ROM Eksorotasi, Abduksi dan Endorotasi serta perbaikan disabilitas shoulder yang signifikan pada penderita Frozen Shoulder.

Berdasarkan tabel 4 diperoleh hasil uji paired sample $t$ yaitu nilai $\mathrm{p}<0,05$ untuk ROM eksorotasi, abduksi, endorotasi dan SPADI (fungsional shoulder), yang berarti intervensi Ultrasound dan Mobilisasi Endrange dapat memberikan peningkatkan ROM Eksorotasi, Abduksi, Endorotasi dan serta perbaikan disabilitas shoulder yang signifikan pada penderita Frozen shoulder.

Berdasarkan tabel 5 diperoleh hasil uji independent sample $t$ diperoleh nilai $p>0,05$ untuk ROM Eksorotasi, Abduksi, dan SPADI yang berarti bahwa tidak ada perbedaan rerata yang signifikan sesudah intervensi antara kelompok perlakuan dan kontrol, namun diperoleh nilai $p \leq 0,05$ untuk $R O M$ Endorotasi yang berarti ada perbedaan rerata yang signifikan antara kelompok perlakuan dan kontrol. Hal ini menunjukkan bahwa tidak ada perbedaan efektifitas antara Ultrasound, Mobilisasi End-range, Mobilisasi Scapula dan Ultrasound, Mobilisasi Endrange terhadap peningkatan ROM Eksorotasi, Abduksi, dan perbaikan 
disabilitas shoulder namun ada perbedaan efektifitas terhadap peningkatan ROM Endorotasi pada penderita frozen shoulder.

Berdasarkan hasil pengujian hipotesis di atas maka dapat disimpulkan bahwa "Penambahan Mobilisasi Scapula pada Ultrasound dan Mobilisasi End-range tidak lebih efektif terhadap perubahan ROM (eksorotasi dan abduksi) dan disabilitas shoulder namun lebih efektif terhadap perubahan ROM endorotasi pada penderita Frozen Shoulder.

\section{PEMBAHASAN}

1. Pengaruh Ultrasound dan Mobilisasi Endrange terhadap perubahan ROM dan disabilitas pada penderita frozen shoulder.

Berdasarkan pengujian hipotesis dengan menggunakan uji paired sample $t$ diperoleh nilai $p<0,05$ untuk ROM eksorotasi, abduksi, endorotasi dan SPADI (fungsional shoulder). Hal ini menunjukkan bahwa kombinasi Ultrasound dan Mobilisasi End-range dapat memberikan peningkatan ROM eksorotasi, abduksi, endorotasi dan serta perbaikan disabilitas shoulder secara bermakna pada penderita Frozen shoulder.

Sebagian besar ahli menjelaskan bahwa frozen shoulder atau biasa dikatakan dengan adhesive capsulitis disebabkan oleh inflamasi kapsul sendi dan synovium yang pada akhirnya menghasilkan formasi kontraktur kapsul. Hal ini dijelaskan bahwa bukan kapsul yang mengalami perlengketan pada humerus sebagaimana dengan istilah "adhesive", melainkan kapsul yang mengikat caput humeri dan fossa glenoidalis mengalami kontraktur atau tight. Secara klinis, keadaan ini yang menyebabkan hilangnya ROM aktif dan pasif pada shoulder terutama pada ROM external rotasi shoulder (Andrea et al, 2017).

Pemberian ultrasound therapy pada kondisi frozen shoulder ditujukan pada jaringan kapsul sendi shoulder yang mengalami kontraktur. Ultrasound adalah modalitas terapeutik yang biasa digunakan untuk memperbaiki ekstensibilitas jaringan ikat, termasuk mengelola atau remodeling jaringan parut, membantu mengurangi rasa sakit pada cedera muskuloskeletal, dan meningkatkan penyembuhan jaringan (Michlovitz et. al 2016).

Penerapan ultrasound therapy dengan frekuensi $1 \mathrm{MHz}$ dapat mencapai kedalaman jairngan sampai 5 atau $6 \mathrm{~cm}$ (James et al, 2016). Dosis ini digunakan pada kondisi frozen shoulder, dimana kedalaman penetrasi gelombang ultrasound tersebut dapat mempengaruhi membran synovial kapsul sendi shoulder yang mengalami tight atau kontraktur sehingga serabut-serabut jaringan ikat pada kapsul sendi akan menjadi lunak dan terjadi perbaikan ekstensibilitas jaringan ikat.

Efek dari ultrasound adalah hasil dari cavitasi dan aliran mikro yang dapat mengubah permeabilitas membran sel, kemudian memfasilitasi penyembuhan jaringan lunak dan viskositas kolagen kapsul sehingga terjadi ekstensibilitas pada kapsul sendi (Safoora et al, 2016).

Penerapan teknik mobilisasi endrange setelah pemberian ultrasound diasumsikan dapat menyebabkan efek yang bermanfaat dan beragam, diantaranya perubahan mekanikal yang mencakup pemecahan adhesion, penataan kembali kolagen atau peningkatan gerak gliding serabut kaspul ligament (Ozgur et al, 2019).

Teknik mobilisasi end-range dalam penelitian ini menggunakan kombinasi distraksi dan glide. Distraksi dapat digunakan untuk melepaskan dan mengurangi tekanan di atas permukaan artikular, merangsang mekanoreseptor kapsul, dan menghasilkan stretch pada capsuloligamentous (Christopher, 2015).

Glide kearah anterior - posterior dalam mobilisasi end-range dapat menghasilkan stretching atau elongasi pada kapsul sendi yang kontraktur pada 
bagian anterior dan posterior, sehingga dapat memperbaiki ROM external dan internal rotasi shoulder. Sedangkan glide kearah inferior dalam mobilisasi endrange dapat menghasilkan stretching atau elongasi pada kapsul sendi yang kontraktur pada bagian inferior sehingga dapat memperbaiki ROM abduksi shoulder (Andrea et al, 2017).

Teknik mobilisasi sendi yang diaplikasikan pada akhir ROM yang ada (end-range) terbukti dapat menghasilkan perbaikan ekstensibilitas kapsul sendi shoulder dan stretch yang terjadi pada jaringan ikat kapsul sendi dapat menghasilkan efek terapeutik yang bermanfaat yaitu peningkatan ROM sendi shoulder (Suzie et al, 2016).

Suatu penelitian membuktikan bahwa pemberian mobilisasi sendi dengan teknik mobilisasi end-range pada kasus Frozen Shoulder sangat efektif terhadap penambahan ROM, dimana peningkatan ROM sangat terlihat pada saat diberikan mobilisasi terutama menggunakan metode Maitland dengan teknik translational mobilization kearah posterior glide glenohumeral (Zusie et al, 2016)

Penelitian lain mengatakan bahwa mobilization dengan teknik glide glenohumeral kearah posterior dan anterior dapat memberikan efek peningkatan ROM eksternal rotasi, internal rotasi dan abduksi pada pasien Frozen shoulder dengan capsulitis adhesive (Andrea et al, 2007).

2. Pengaruh Ultrasound, Mobilisasi endrange dan Mobilisasi Scapula terhadap perubahan ROM dan disabilitas pada penderita frozen shoulder.

Berdasarkan pengujian hipotesis dengan menggunakan uji paired sample $t$ diperoleh nilai $p<0,05$ untuk ROM eksorotasi, abduksi dan endorotasi serta SPADI (fungsional shoulder). Hal ini menunjukkan bahwa kombinasi Ultrasound, Mobilisasi End-range dan Mobilisasi scapula dapat memberikan peningkatan ROM Eksorotasi, abduksi dan endorotasi serta perbaikan disabilitas shoulder secara bermakna pada penderita Frozen Shoulder.

Pada kelompok perlakuan terdapat penambahan mobilisasi scapula pada intervensi ultrasound dan mobilisasi endrange. Telah dijelaskan bahwa ultrasound dapat menghasilkan efek terapeutik berupa perbaikan ekstensibilitas jaringan kapsul sendi shoulder yang mengalami tight atau kontraktur. Begitu pula telah dijelaskan bahwa mobilisasi end-range dapat menghasilkan efek stretching pada jaringan kapsul sendi shoulder sehingga secara progresif dapat terjadi pemanjangan kapsul sendi shoulder atau peningkatan ekstensibilitas kapsul sendi.

Mobilisasi scapula telah terbukti menjadi penatalaksanaan terapi yang efektif untuk meningkatkan mobilitas bahu pada pasien dengan capsulitis adhesive (Agarwal, 2016). Beberapa penelitian menemukan bahwa irama gerak scapulohumeral yang abnormal sering muncul setelah masa pengobatan. Gangguan irama gerak scapulohumeral sering ditemukan setelah 8 minggu pengobatan, begitu pula adanya penonjolan ujung scapula kearah posterior. Penemuan ini menunjukan secara spesifik pentingnya mobilisasi scapula yang dikombinasikan dengan mobilisasi end-range pada shoulder joint (Jing-lan Yang, 2012).

Berdasarkan penelitian membuktikan bahwa gerakan scapula akan meningkat $4^{0}$ disertai dengan peningkatan fleksi shoulder sebesar $8^{0}$ dan abduksi shoulder sebesar $6^{0}$ setelah diberikan mobilisasi scapula. Penelitian baru-baru ini menemukan bahwa peningkatan rasio fleksi shoulder dengan gerakan scapula yaitu 8:4 tapi tidak sama dengan peningkatan rasio abduksi shoulder setelah aplikasi mobilisasi scapula. Hal ini disebabkan oleh adanya tightness kapsul bagian inferior yang dapat mempengaruhi peningkatan abduksi shoulder. Selain itu, mobilisasi scapula dapat memecah dan melepaskan 
adhesion pada otot-otot di daerah scapulothoracic joint sehingga gerakan scapula dapat meningkat (Ozgur et al, 2014).

Beberapa penelitian sebelumnya tentang mobilisasi scapula menunjukkan bahwa mobilisasi scapula dapat menghasilkan perbaikan ROM shoulder dan disabilitas shoulder, dimana adanya perbaikan gerakan scapula dan shoulder dapat menghasilkan status fungsional shoulder yang lebih baik. Jiu Jeng et al menemukan bahwa kinematik scapula sangat penting dalam menunjukkan disabilitas fungsional pada pasien frozen shoulder sehingga mobilisasi scapula sangat penting dalam membantu menurunkan disabilitas fungsional pada penderita frozen shoulder (Ozgur et al, 2014).

3. Efektifitas antara kombinasi ultrasound, mobilisasi end-range, mobilisasi scapula dan kombinasi ultrasound, mobilisasi endrange terhadap perubahan ROM dan disabilitas shoulder pada penderita frozen shoulder.

Berdasarkan pengujian hipotesis dengan menggunakan uji independent sample $t$ diperoleh nilai $\mathrm{p}>0,05$ untuk gerakan eksorotasi, abduksi, endorotasi dan SPADI yang berarti bahwa tidak ada perbedaan yang signifikan rerata sesudah intervensi antara kelompok perlakuan dan kontrol. Hal ini menunjukkan bahwa tidak ada perbedaan yang bermakna antara Ultrasound, Mobilisasi end-range, Mobilisasi Scapula dan Ultrasound, Mobilisasi end-range terhadap perubahan ROM dan disabilitas shoulder pada kondisi Frozen shoulder.

Menurut para ahli, glenohumeral joint dan scapulothoracic joint termasuk kedalam closed kinetic chain. Para ahli berasumsi bahwa jika mobilisasi sendi glenohumeral dapat memperbaiki gerakan shoulder dan menormalkan irama gerak scapulohumeral maka mobilisasi scapula akan dapat memperbaiki gerakan shoulder, hal ini karena adanya hubungan kinematika antara shoulder dan scapula. Meskipun demikian, beberapa penelitian telah menunjukkan bahwa mobilisasi sendi shoulder dapat memberikan input sensorik yang cukup untuk mengaktivasi sistem endogenous pain-inhibitory, berbeda dengan mobilisasi scapula yang lebih banyak berhubungan dengan struktur otot daripada sendi synovial sehingga ditemukan adanya perbedaan penurunan nyeri setelah aplikasi mobilisasi sendi shoulder dan mobilisasi scapula, dimana tidak terjadi penurunan nyeri shoulder yang signifikan setelah aplikasi mobilisasi scapula.

Berdasarkan teori di atas, menunjukkan bahwa mobilisasi scapula lebih banyak memperbaiki alignment scapula karena adanya problem keterbatasan gerak shoulder dapat mempengaruhi posisi scapula yang cenderung menonjol ke belakang. Selain itu, mobilisasi scapula merangsang proprioceptor otot scapula bukan mechanoreceptor sendi shoulder sehingga tidak berhubungan langsung dengan problem sendi shoulder. Hal ini yang mempengaruhi penambahan mobilisasi scapula pada intervensi ultrasound dan mobilisasi end-range tidak lebih efektif, meskipun perbaikan gerakan scapula dan shoulder dapat menghasilkan status fungsional shoulder yang lebih baik.

\section{KESIMPULAN}

1. Kombinasi Ultrasound, Mobilisasi Endrange dan Mobilisasi scapula dapat memberikan pengaruh yang signifikan terhadap perubahan ROM dan disabilitas pada penderita frozen shoulder.

2. Intervensi Ultrasound dan Mobilisasi Endrange dapat memberikan pengaruh yang signifikan terhadap perubahan ROM dan disabilitas pada penderita frozen shoulder.

3. Kombinasi ultrasound, mobilisasi endrange dan mobilisasi scapula tidak lebih efektif daripada kombinasi ultrasound dan mobilisasi end-range terhadap perubahan 
ROM dan disabilitas shoulder pada penderita frozen shoulder.

\section{DAFTAR PUSTAKA}

Ansar, Sudaryanto, Halima.A, Hendrik. 2017. Buku Panduan Skripsi Prodi D. IV Fisioterapi. Makassar : Poltekes Kemenkes Makassar.

Andrea, J. Jonson., Joseph J. Godges., Grenith J. Zimmerman., 2017. The Effect of Anterior Versus Posterior Glide Joint Mobilization On Eksternal Rotation Range Of Motion in Patient With Shoulder Adhesive Capsulitis. The Journal Of Orthopedic \& Sports Physical Therapy: Vol.37 No.3

Agarwal, S., Raza, S., Moiz A. L., Anwer.S, Alghadir, A. 2016. Effects of two different mobilization techniques on pain, range of motion and functional disability in patients with adhesive capsulitis: a comparative study. The Journal Of Physical Therapy Science : Vol.28 No. 3342-3349

Arovah, Nova, Intan. 2010. Dasar-dasar Fisioterapi Pada Cedera Olahraga. http://ryrilumoet.blogspot.com.

Yogyakarta < diakses 28 januari 2019>

Bellew, J.W., Michlovitz, S.L., Nolan, T.P. 2016. Modalitoes For Therapeutic Interventation. Sixth Edition. Philadelphia: Goerge W. lang.

Cristhoper, H.W. 2015. Orthopaedic Manual Phisical Therapy. Philadelphia: Goerge W. Lang.

Cui, J., Lu, W., He, Y., Jiang, L., Li, K., Zhu, W., Wang, D. 2019. Moleculer Biology Of Frozen Shoulder-Induced Limitation Of Shoulder Joint Movement Journal Of Research In Medical Sciences: $\mathrm{p}$ 114.4.219.84.

Donatelli, A. R. 2011. Physical Therapy Of The Shoulder. Fifth Edition. Las Vegas: Julie Eddy and Rajendrababu Hemamalini.

Duwi Priyanto. 2011. Buku Saku Analisis Statistik Data Dengan SPSS. Yogyakarta: Mediakom
Ebadi, S., Forogh, B., Fallah, E., Ghazani, A.B. 2014. Journal Of Bodywork and Movement Therapies.Iran.

Elly, H., Kevin, B. 2015. Mitland's Peripheral Manipulation. Fourth Edition. London New York: Peter Wells.

Elly, H., Kevin, B. 2015. Mitland's Peripheral Manipulation. Fifth Edition. London New York: Matthew Newton.

Elfindri, Hasnita Evi, Abidin Zainal, Machmud Elmiyasna Rizanda. 2012. Metodologi Penelitian Kesehatan. Jakarta : Baduose Media Jakarta.

Kelley, J. M., Phillip, W.M., Brian, G.L. 2017. Frozen Shoulder: Evidence and $A$ Proposed Model Guiding Rehabilitation. Journal Of Orthopedic and Sports Physical Therapy: Vol.39 No.2 p.135-148.

Kelley, J Martin., Shaffer, A Michael., Kuhn, E John.,et al.2013. Shoulder Pain and Mobility Deficits: Adhesive Capsulitis. The Journal of Orthopaedic \& Sports Physical Therapy Vol 43 Number 5 May

Kisner, C., Colby, A.L. 2012. Therapeutic Exercise Foundation and Techniques. Sixth Edition. Philadelphia : FA. Davis Company.

Magee, D. J. 2014. Orthopedic Physical Assesment. Sixth Edition, Faculty Of Rehabilitation Medicine University Of Alberta Edmonto, Canada : Deborah Vogel.

Manske RC, and Prohaska D. Diagnosis and management of adhesive capsulitis. Current Reviews in Musculoskeletal Medicine. 2011;1(3-4):180-189.

MacDermid, J. C., Solomon, P., and Prkachin, K. (2016). The Shoulder Pain and Disability Index demonstrates factor, construct and longitudinal validity. BMC Musculoskeletal Disorders, 7:12.

Miharjanto H. Kuntono HP. Setiawan D. 2010. Perbedaan Pengaruh Antara Latihan Konvensional Ditambah Latihan Plyometrics dan Latihan Konvensional Terhadap Pengaruh Nyeri, dan Disabilitas Penderita 
FrozenShoulder. 3. 2 : November 2010: 2

Michlovitz, S.L, Bellew, J.W., Jr, T.P.N.2012. Modalitas For Therapeutic Intervention, Fifth Edition. Philadelphia : F.A Davis Company.

Morgan, W.E and Potthoff, S; 2012, Managing the Frozen Shoulder: Selfcare manual for those suffering from frozen shoulder. e-book, diakses tanggal 18/01/2019.

Moulin DE, Clark AJ, Speechley M, Morley PK. Chronic Pain In Canadaprevelence, Treatment, Impact and The Role Of Opioid Analgesia. Pain Res Manag.2012;7:179-84

Nordin, M., Frankel, H. V. 2012. Basic Biomechanics Of The Musculoskeletal System. Fourth Edition. New York : Julie K. Steqman.

Nancy, B. R., William, D.B. 2002. Joint Range Of Motion and Muscle Length Testing.London : Gay Barber.

Norkin, C.C., White, J.D. 2016. Measurement Of Joint Motion. Fifth Edition. Philadelphia: F.A Davis Company.

Neumann, DA. 2010. Shoulder complex. In Neumann DA: Kinesiology of the Musculoskeletal System: Foundations for Physical Rehabilitation. Philadelphia: Mosby. Chapter 5, pp. 91-132

Oatis, A.C. 2015. Kinesiology The Mechanic and Pathomechanics Of Human Movement. Second Edition. India: Sanny Ally Gover.

Ozgur Surenkok., Aydan Aytar., and Gul Baltaci (2019). Acute Effect Of Scapular Mobilization in Shoulder Dysfunction : Journal of Sport Rehabilitation : Vol.18 No. 493-501

Porterpield, A.J., DeRossa, C. 2014. Principles Of Mechanical Shoulder Disorders. Amerika serikat: John Rogers.
Pubz, R dan Pabst, R. 2012. Atlas Anatomi Manusia; Sobotta Anatomi; Edisi 21, Buku Kedokteran EGC; Jakarta

Roach, K. E., Budiman-Make, E., Songsirideg, N., and Lertratanakul, Y. (2012). Development of a shoulder pain and disability index. Arthritis Care Res, 4(4):143-9.

Safoora Ebadi., (2016) Does Ultrasound therapy add to the effects of exercise and mobilization in frozen shoulder. Journal Bodywork and Movement Therapies

Suzie Noten. McS., Mira Meues. PhD., Gaetane Stassjins.,MD. PhD. (2016) Eficacy Of Different Thypes Of Mobilization Technique in Patient With Primary Adhesive Capsulitis Of The Shoulder. American Congress of Rehabilitation Medicine :Vol. 15 No.003-9993

Sopiyudin, D. 2016. Besar Sampel Dalam Penelitian Kedokteran Dan Kesehatan Seri . Edisi 4 Jakarta. Epidemiologi Indonesia

Yang, J., Mei, H., Chein, W., Jiu, J. 2012. Effectiveness Of The End-range Mobilization and Scapular Mobilization Approach In A Subgroup Of Subject With Frozen Shoulder Syndrome : A Randomized Control Trial. Journal Home Page : www. Elsevier.com/math: p. 47-52.

Yamuna, Kumar, S., Krishna, R., Madhavik, K. 2018. Effectiveness of scapular and glenohumeral mobilization on range of motion and disability of shoulder in subjects with periarthritis of shoulder. International Educational Scientific Research Journal : Vol. 4 No. 2455295X

Zuckerman, J.D., Rokito, A. 2011. Frozen shoulder : A Concensus Definition.J Shoulder Elbow Surg:V 20 p 322-325. 
Tabel 1

Rerata Sampel berdasarkan Umur Di RS.Tadjuddin Chalid Makassar

\begin{tabular}{|c|c|c|c|c|c|c|}
\hline \multirow{2}{*}{$\begin{array}{c}\text { Karakteristik } \\
\text { Sampel }\end{array}$} & \multicolumn{3}{|c|}{ Kelompok Perlakuan } & \multicolumn{3}{|c|}{ Kelompok Kontrol } \\
\hline & Rera ta & Min & Max & Rera ta & Min & Max \\
\hline Umur (tahun) & $56.14 \pm 9.12$ & 40 & 70 & $54.43 \pm 11.47$ & 40 & 73 \\
\hline \multirow[t]{2}{*}{$\begin{array}{c}\text { Karakteristik } \\
\text { Sampel }\end{array}$} & \multicolumn{2}{|c|}{ Kelompok perlakuan } & \multicolumn{4}{|c|}{ Kelompok kontrol } \\
\hline & $\mathrm{n}$ & $\%$ & & $\mathrm{n}$ & $\%$ & \\
\hline $\begin{array}{l}\text { Jenis } \\
\text { kelamin : } \\
\text { Laki-laki } \\
\text { Perempuan }\end{array}$ & $\begin{array}{l}2 \\
5\end{array}$ & $\begin{array}{l}28,6 \\
71,4\end{array}$ & & $\begin{array}{l}2 \\
5\end{array}$ & $\begin{array}{l}28,6 \\
71,4\end{array}$ & \\
\hline
\end{tabular}

Tabel 2

Rerata ROM dan SPADI berdasarkan nilai pre test, post test, dan selisih

\begin{tabular}{lccc}
\hline \multirow{2}{*}{ Kelompok Sampel } & \multicolumn{3}{c}{ Rerata dan Simpang Baku } \\
\cline { 2 - 4 } Kelompok Perlakuan & Pre test & Post test & Selisih \\
Eksorotasi & $45.86 \pm 6.09$ & $74.57 \pm 4.61$ & $28.71 \pm 6.42$ \\
Abduksi & $90.00 \pm 16.07$ & $127.86 \pm 16.29$ & $37.86 \pm 18.45$ \\
Endorotasi & $53.57 \pm 5.74$ & $73 \pm 3.83$ & $19.43 \pm 6.13$ \\
SPADI & $58.90 \pm 4.53$ & $24.18 \pm 1.82$ & $34.72 \pm 3.31$ \\
\hline Kelompok Kontrol & & & \\
Eksorotasi & $57.43 \pm 8.42$ & $75.57 \pm 8.14$ & $18.14 \pm 6.54$ \\
Abduksi & $98.57 \pm 12.49$ & $127.14 \pm 7.56$ & $28.57 \pm 13.76$ \\
Endorotasi & $49.29 \pm 12.05$ & $67.14 \pm 5.93$ & $17.86 \pm 13.36$ \\
SPADI & $59.23 \pm 1.66$ & $26.26 \pm 1.96$ & $32.97 \pm 3.03$ \\
\hline
\end{tabular}

Tabel 3

Uji Beda Rerata ROM dan SPADI Sebelum Dan Sesudah Intervensi Pada Kelompok Perlakuan

\begin{tabular}{|c|c|c|c|c|}
\hline Kelompok Data & Sebelum & Sesudah & $\mathrm{t}$ & $p$ \\
\hline $\begin{array}{l}\text { Eksorotasi } \\
\text { Rerata }\end{array}$ & 45.86 & 74.57 & \multirow{2}{*}{-11.83} & \multirow[b]{2}{*}{0,000} \\
\hline Simpang Baku & 6.094 & 4.61 & & \\
\hline Abduksi & & & \multirow{3}{*}{-5.428} & \multirow{3}{*}{0,002} \\
\hline Rerata & 90.00 & 127.86 & & \\
\hline Simpang Baku & 16.07 & 16.29 & & \\
\hline $\begin{array}{l}\text { Endorotasi } \\
\text { Rerata }\end{array}$ & 53.57 & 73.00 & \multirow{3}{*}{-8.381} & \multirow{3}{*}{0,000} \\
\hline Simpang Baku & 5.74 & 3.83 & & \\
\hline SPADI & & & & \\
\hline Rerata & 58.90 & 24.18 & \multirow[b]{2}{*}{27.786} & \multirow[b]{2}{*}{0,000} \\
\hline Simpang Baku & 4.53 & 1.82 & & \\
\hline
\end{tabular}

Vol. XV No. 2, Desember 2020 
Tabel 4

Uji Beda Rerata ROM dan SPADI

Sebelum Dan Sesudah Intervensi Pada Kelompok Kontrol

\begin{tabular}{|c|c|c|c|c|}
\hline $\begin{array}{l}\text { Kelompok } \\
\text { Data }\end{array}$ & Sebelum & Sesudah & $\mathrm{t}$ & $p$ \\
\hline \multicolumn{5}{|l|}{ Eksorotasi } \\
\hline Rerata & 57.43 & 75.57 & \multirow{2}{*}{-7.336} & \multirow{2}{*}{0,000} \\
\hline Simpang Baku & 8.42 & 8.14 & & \\
\hline \multicolumn{5}{|l|}{ Abduksi } \\
\hline Rerata & 98.57 & 127.14 & \multirow{2}{*}{-5.494} & \multirow{2}{*}{0,002} \\
\hline Simpang Baku & 12.49 & 7.56 & & \\
\hline \multicolumn{5}{|l|}{ Endorotasi } \\
\hline Rerata & 49.29 & 67.14 & \multirow{3}{*}{-3.536} & \multirow{3}{*}{0,012} \\
\hline Simpang Baku & 12.05 & 5.93 & & \\
\hline \multicolumn{3}{|l|}{ SPADI } & & \\
\hline Rerata & 59.23 & 26.26 & \multirow[b]{2}{*}{28.828} & \multirow[b]{2}{*}{0,000} \\
\hline Simpang Baku & 1.66 & 1.96 & & \\
\hline
\end{tabular}

Tabel 5

Uji beda rerata sesudah $R O M$ dan SPADI antara kelompok perlakuan dan kelompok kontrol

\begin{tabular}{|c|c|c|c|c|}
\hline Data & $\begin{array}{l}\text { Kelom pok } \\
\text { Perlakuan }\end{array}$ & $\begin{array}{c}\text { Kelom pok } \\
\text { Kontrol }\end{array}$ & $\mathrm{t}$ & $\mathrm{p}$ \\
\hline \multicolumn{5}{|l|}{ Eksorotasi } \\
\hline Rerata & 74.57 & 75.57 & \multirow{2}{*}{-0.283} & \multirow{2}{*}{0.782} \\
\hline Simpang Baku & 4.61 & 8.14 & & \\
\hline \multicolumn{5}{|l|}{ Abduksi } \\
\hline Rerata & 127.86 & 127.14 & \multirow{2}{*}{0.105} & \multirow{2}{*}{0.918} \\
\hline Simpang Baku & 16.29 & 7.56 & & \\
\hline \multicolumn{5}{|l|}{ Endorotasi } \\
\hline Rerata & 73.00 & 67.14 & \multirow{2}{*}{2.196} & \multirow{2}{*}{0.049} \\
\hline Simpang Baku & 3.83 & 5.93 & & \\
\hline \multicolumn{5}{|l|}{ SPADI } \\
\hline Rerata & 24.18 & 26.26 & \multirow[t]{2}{*}{-2.065} & \multirow{2}{*}{0.061} \\
\hline Simpang Baku & 1.82 & 1.96 & & \\
\hline
\end{tabular}

